\title{
Increased planting speed did not affect silage and grain yield of maize, while saving seed and energy
}

\author{
Filip Vučajnk, ${ }^{1}$ Igor Šantavec, ${ }^{1}$ Darja Kocjan Ačko, ${ }^{1}$ Jurij Rakun, ${ }^{2}$ Jože Verbič, ${ }^{3}$ Rajko Bernik, ${ }^{1}$ \\ Stanislav Trdan, ${ }^{1}$ Matej Vidrih ${ }^{1}$ \\ ${ }^{1}$ Department of Agronomy, Biotechnical Faculty, University of Ljubljana; ${ }^{2}$ Department of Biosystems \\ Engineering, Faculty of Agriculture and Life Sciences, University of Maribor; ${ }^{3}$ Agricultural Institute of \\ Slovenia, Department of Animal Production, Ljubljana, Slovenia
}

\begin{abstract}
Optimal planting speed of vacuum maize planters is usually suggested by planter's manufacturers, while increased planting speed may influence plant spacing and finally yield. Our hypothesis was that by increasing planting speed over the suggested level plant spacing variability will also increase which will result in decrease of silage and grain yield and saving of seed and energy. The field trial consisted of three planting speeds of 7, 9 and 11 $\mathrm{km} / \mathrm{h}$ in the form of random blocks. The following measurements were taken as follows: plant spacing, silage and grain yield, fuel and energy use at planting. Results in this study show that planting speed did not have significant influence on silage and grain yield of maize, while up to $10 \%$ less seed was needed per hectare and fuel and energy use was lower for $15 \%$. By the increase of planting speed the distance between the plants in a row, and in most cases also the plant spacing variability increased. It was noticed that by increasing planting speed plant density decreased. This research established that at higher planting speeds significant increase of the silage yield per individual plant and of the grain yield per individual plant was achieved. The ear parameters also show that the kernel mass per individual ear, the ear mass, and the cob mass, as well as the individual kernel mass, are larger at the planting speed of $11 \mathrm{~km} / \mathrm{h}$ than at the planting speed of $7 \mathrm{~km} / \mathrm{h}$. At the latter planting speed, significantly higher fuel consumption per
\end{abstract}

Correspondence: Filip Vučajnk, Department of Agronomy, Biotechnical Faculty, University of Ljubljana, Jamnikarjeva 101, 1000 Ljubljana, Slovenia.

Tel.: +386.13203131 - Fax: +386.14231088 .

E-mail: filip.vucajnk@bf.uni-lj.si

Key words: Energy use; grain yield; maize; planting speed; plant spacing; seed savings; silage yield; vacuum planter.

Received for publication: 2 March 2020.

Revision received: 27 June 2020.

Accepted for publication: 27 June 2020.

(C) Copyright: the Author(s), 2020

Licensee PAGEPress, Italy

Italian Journal of Agronomy 2020; 15:1612

doi:10.4081/ija.2020.1612

This article is distributed under the terms of the Creative Commons Attribution Noncommercial License (by-nc 4.0) which permits any noncommercial use, distribution, and reproduction in any medium, provided the original author(s) and source are credited. hectare and higher energy use was achieved than at the other two planting speeds. Overall the main benefits of planting speed of 11 $\mathrm{km} / \mathrm{h}$ is saving seed and energy at planting while maintaning the same level of silage and grain yield compared to lower planting speeds used in the trial.

\section{Introduction}

Modern maize planters have the ability to evenly distribute seeds on the seed plate, yet the actual distances between the plants in a row usually vary (Nielsen, 2001). The spacing of plants in a row can vary due to technical problems of planters, poor maintenance, lower seed germination, inappropriate soil preparation, soil temperature, soil moisture, and some other factors. Yazgi (2016) also stated that the seed tube geometry of a maize vacuum planter had a significant impact on seed spacing uniformity. The standard deviation is not the most relevant information, as it depends on the squared deviation from the mean and is strongly influenced primarily by large distances between plants, the so-called miss places. Kachman and Smith (1995) introduced new criteria for determining spacing between the plants in a row based on the theoretical spacing between the plants in a row.

More uniform within-row spacing is expected to decrease competition between neighbouring plants and produce higher grain yields with better use of light, water, and nutrients (Schubeck and Young, 1970). The results of various studies dealing with the effects of within-row plant spacing variability on maize grain yield differ. Early studies show that more even within-row plant spacing did not increase grain yield (Ehrbach et al., 1972; Muldoon and Daynard, 1981). Liu et al. (2004), having experimented for several years at different locations, found that the maize grain yield was not significantly influenced by the plant spacing variability. In contrast to this, some studies have shown that the plant spacing variability reduced the maize grain yield. Krall et al. (1977) reported that a $1 \mathrm{~cm}$ increase in the standard deviation reduced the grain yield by $84 \mathrm{~kg} / \mathrm{ha}$. Vanderlip et al. (1988) found out that the grain yield decreased if the standard deviation exceeded $6 \mathrm{~cm}$.

Planting speeds have increased in response to mechanical improvements. The research by Staggenborg et al. (2004) examined how planting speeds and the improved devices affected plant emergence, plant spacing variability, and final grain yield. Increasing the speed correlated with increased plant spacing variability, while final grain yield was unaffected by planting speed. Virk et al. (2020) evaluated planter performance during variablerate seeding with treatments consisting of two seed metering units with five different seeding rates and four planting speed treat- 
ments which represented a combination of 20 different seed meter speeds. Plant spacing coefficient of variation increased with an increase in seed meter speed, due to the fact that meter speed is a function of seeding rate and ground speed. Nielsen (1995) recorded the reduced maize grain yield at increased planting speed at 5 of 22 experimental locations. The increase of planting speed from 6.4 $\mathrm{km} / \mathrm{h}$ to $11.3 \mathrm{~km} / \mathrm{h}$ at these five experimental locations reduced the grain yield by $383-948 \mathrm{~kg} / \mathrm{ha}$.

Studies which simultaneously involve planting speeds, plant spacing variability, silage yields, grain yields, fuel and energy use are scarce. For this reason, we carried out an experiment with three planting speeds $-7,9$, and $11 \mathrm{~km} / \mathrm{h}$ - with an air vacuum planter in the years 2013, 2015, and 2016. The objective of our study was to determine the effects of higher planting speeds than suggested on the within-row spacing of plants, on the silage yield and the grain yield of maize and also on fuel and energy requirement. We hypothesized that by increasing planting speed, plant spacing variability will also increase which will lead to a decrease in the silage and grain yield.

\section{Materials and methods}

\section{Field trial}

The field experiment was designed as random blocks in the years 2013, 2015, and 2016 in Globodol, Slovenia (45 50'27"N, $\left.15^{\circ} 2^{\prime} 51^{\prime \prime} \mathrm{E}\right)$. The soil texture was silty clay, and the soil contained $26.2 \%$ of clay. Detailed soil characteristics and physical soil properties are presented in Tables 1 and 2 . The experiment involved three planting speeds: $7.0 \mathrm{~km} / \mathrm{h}, 9.0 \mathrm{~km} / \mathrm{h}$, and $11.0 \mathrm{~km} / \mathrm{h}$ with 3 blocks (replications). The total length of an individual block was $200 \mathrm{~m}$, while its width was $3 \mathrm{~m}$ or 4 rows. An individual experimental plot was divided into four $50 \mathrm{~m}$-long sections, and within these sections the measurements were carried out. Four side rows were planted on both sides of the experimental site.

\section{Planting speed}

The planting was carried out with a 4-row air vacuum maize planter ED 302 Contour manufactured by Amazone. All adjusted planting speeds were measured on the tractometer. The planting was carried out by the tractor Fendt 513 Vario, with a continuously variable transmission. Each individual planting speed was set by a cruise control, while the motor-rotational frequency was $1340 \mathrm{~min}^{-1}$ and the PTO rotational frequency was $710 \mathrm{~min}^{-1}$. The air pressure on seeding plates during planting was 75 mbar.

The maize hybrid was P 9721, which belonged to the maturity class FAO 390. It is suitable for both grain and silage production. The planter gearbox was set to the theoretical spacing of $16.5 \mathrm{~cm}$ between the seeds in a row. Each seed plate had 30 holes, with a density of 80,808 plants per hectare at the inter row width of 75 $\mathrm{cm}$. The planting depth was set at $5.0 \mathrm{~cm}$. In front of each seeding coulter a clod remover was fixed. Each seed plate was equipped with a photocell which provided the data on density of planting for individual rows. The data on density of planting per hectare was monitored for each row by the computer Amascan ${ }^{+}$, while the working pressure was monitored on the manometer in the tractor's cabin. In 2016, we measured the fuel consumption per hour at each planting speed on the Varioterminal 10.4-B simultaneously with planting. The fuel consumption per hectare was calculated by dividing the fuel consumption per hour $(\mathrm{L} / \mathrm{h})$ with the work rate (ha/h). Furthermore energy use was expressed by multiplying fuel use (L/ha) with fuel density $(\mathrm{kg} / \mathrm{L})$ and fuel heating value $(\mathrm{MJ} / \mathrm{kg})$.

\section{Plant spacing}

One measurement point within each of the four smaller sections ( $50 \mathrm{~m}$ long) was randomly chosen in order to measure the distances between plants in a row, and later also the silage yield and the grain yield. The distances between plants in the row were measured in the length of $13.33 \mathrm{~m}$, which corresponded the area of 10 $\mathrm{m}^{2}$.The distances between the centers of stalks of two neighboring plants were measured with autonomic field robot CornStar. The robot was driven through the rows of maize. LIDAR sensor was used for the measurements and it measured the distances between sensor and plants in the angle area of $270^{\circ} \pm 1^{\circ}$ and the frequency of $15 \mathrm{~Hz}$. The mean distance between the plants in a row and the standard deviation $\left(\mathrm{SD}_{\mathrm{ALL}}\right)$ were calculated on the basis of the distances between the plants in a row. Then, according to Kachman and Smith (1995), the Multiple Index, the Miss Index, the Quality of Feed Index, and precision $\mathrm{C}$ were calculated. From measured distances which were between 8.3 and $24.8 \mathrm{~cm}(0.5-1.5 \mathrm{x}$ target distance) we calculated $\mathrm{SD}_{\mathrm{REF}}$. This $\mathrm{SD}_{\mathrm{REF}}$ includes only singles and not doubles and triples. Multiple Index is defined as the percentage of distances between plants which are smaller than $8.3 \mathrm{~cm}$ $(<0.5 \times$ target distance $)$ and Miss Index represents the percentage of distances which are greater than $24.8 \mathrm{~cm}(>1.5 \times$ target distance $)$ from all measured distances between plants. Precision $C$ represents the quotient between $\mathrm{SD}_{\mathrm{REF}}$ and the target distance between plants $(16.5 \mathrm{~cm})$ and it is expressed in percentages. Quality of Feed Index is defined as the percentage of distances which are not Multiple and not Miss Index. We get the Quality of Feed Index when Multiple and Miss Index are deducted from 100\%. Single skips (1.5-2.5 $\times$ the theoretical spacing), double skips $(2.5-3.5 \times$ the theoretical spacing), and triple skips $(>3.5 \times$ the theoretical spacing) were also determined. All results were obtained on the basis of the theoretical spacing between the plants in a row, which was 16.5 $\mathrm{cm}$. The plant density per hectare was calculated from the number of plants per $10 \mathrm{~m}^{2}$.

\section{Silage yield and grain yield}

An individual measurement point with the length of $13.33 \mathrm{~m}$ was halved. Thus, the plant samples were taken in order to determine the silage yield at the distance of $6.67 \mathrm{~m}$. Individual plants were cut manually $10 \mathrm{~cm}$ above the ground. All plants for silage were cut and their total mass was determined using hanging scales UWE CCS-60 K with precision of $0.02 \mathrm{~kg}$ in the measuring range

Table 1. Soil analysis.

\begin{tabular}{cccccc} 
Depth (cm) & $\begin{array}{c}\mathrm{pH} \\
\text { in } \mathrm{CaCl}\end{array}$ & $\begin{array}{c}\mathrm{P}_{2} \mathrm{O} 5 \\
(\mathrm{mg} / 100 \mathrm{~g})\end{array}$ & $\begin{array}{c}\mathrm{K}_{2} \mathrm{O} \\
(\mathrm{mg} / 100 \mathrm{~g})\end{array}$ & $\begin{array}{c}\text { Org. matter } \\
(\%)\end{array}$ & $\begin{array}{c}\mathrm{C} \\
(\%)\end{array}$ \\
\hline-30 & 5.1 & 4.4 & 30.6 & 3.4 & 2.0 \\
\hline
\end{tabular}

Table 2. Physical soil properties at planting in 2015.

\begin{tabular}{lcc}
$\begin{array}{c}\text { Soil density } \\
\left(\mathrm{g} / \mathrm{cm}^{3}\right)\end{array}$ & $\begin{array}{c}\text { Soil porosity } \\
(\%)\end{array}$ & $\begin{array}{c}\text { Water content } \\
(\%)\end{array}$ \\
$1.37 \pm 0.12$ & $48.3 \pm 4.4$ & $44.7 \pm 4.0$ \\
\hline
\end{tabular}


of $60 \mathrm{~kg}$. The plants collected from $5.0 \mathrm{~m}^{2}$ were harvested with the single-row silage harvester Sip Silo 80 B. From each sample of the chopped mass individual sample for the analysis of dry matter was taken. The samples were immediately weighed and placed into a dryer at a temperature of $60^{\circ} \mathrm{C}$ and dried to a constant mass. The samples were weighed again after drying. From these data, the silage yield per hectare, the dry matter content, and the dry matter yield per hectare were calculated. At a length of $6.67 \mathrm{~m}\left(5.0 \mathrm{~m}^{2}\right)$ in the row, the grain yield was measured. At this length in the row, 10 maize ears were randomly picked. These ears were dried in a dryer at the temperature of $40^{\circ} \mathrm{C}$. At the beginning, the number of kernel rows on individual ears were counted. After that, the ears were manually shelled and the number of kernels per ear were counted. The total ear mass with kernels, the ear mass without kernels (cob mass) and the kernel moisture were also measured. At the end, the ears from the remaining plants at the length of $6.67 \mathrm{~m}$ were picked. These ears were dried and then processed with a tractor maize sheller. The grain moisture was measured with the moisture meter Pfeuffer, HE 50. These data were used to calculate the grain yield per hectare at $14 \%$ moisture. The field trials were not irrigated. Particularly in period from June to August 2013, 2015, 2016 the average daily temperature was higher for 1 to $3^{\circ} \mathrm{C}$ compared to long-term average of 1981-2010. In all three growing periods 2013, 2015 and 2016 less rain was recorded in June, July and August. The year 2013 was special as in time period from June to August received $220 \mathrm{~mm}$ less precipitation compared to long-term average 1981-2010. In growing season of 2013 and 2016 there was less rain from the average of 1981-2010, while in 2015 season October received extremely large amount of precipitation (Table
$3)$. In 2013, the distances between the plants in a row were measured only, while in 2015 and 2016 the silage yield and the grain yield was also analysed. The year 2013 was marked by a severe drought, so any results concerning the yield of silage and grain would be incomparable.

\section{Statistical analysis}

The data was statistically processed with the program Statgraph Centurion XVI (Statpoint Technologies), according to the procedure for random blocks. The analysis of variance and Duncan's multiple comparison test were carried out. If significant differences emerged $(\mathrm{P}<0.05)$, they were marked with different letters. The correlation between variables was determined by using Pearson product moment correlations.

\section{Results}

\section{Plant spacing variability}

The mean distance between the plants in a row in all years of the experiment significantly increased with planting speed from 7 to $11 \mathrm{~km} / \mathrm{h}$ (Table 4). The nearest mean distance compared to theoretical spacing $16.5 \mathrm{~cm}$ was achieved at the planting speed of 7 $\mathrm{km} / \mathrm{h}$. The standard deviation, which comprised all distances between the plants in a row, was also significantly increasing with the increase of planting speed from $7 \mathrm{~km} / \mathrm{h}$ to $11 \mathrm{~km} / \mathrm{h}$. Since this

Table 3. Weather information for the crop season of 2013, 2015 and 2016.

\begin{tabular}{|c|c|c|c|c|c|c|c|c|c|}
\hline \multirow[b]{2}{*}{ Month } & \multicolumn{4}{|c|}{$\mathrm{T}\left({ }^{\circ} \mathrm{C}\right)$} & & \multicolumn{4}{|c|}{ Precipitation (mm) } \\
\hline & 2013 & 2015 & 2016 & $1981-2010$ & & 2013 & 2015 & 2016 & $1981-2010$ \\
\hline April & 12.1 & 11.3 & 12.3 & 10.6 & & 66 & 54 & 63 & 89 \\
\hline May & 14.9 & 16.8 & 15.4 & 15.5 & & 167 & 165 & 118 & 97 \\
\hline June & 19.4 & 20.2 & 19.8 & 18.7 & & 39 & 86 & 117 & 131 \\
\hline July & 22.8 & 23.8 & 22.5 & 20.7 & & 15 & 86 & 74 & 99 \\
\hline August & 22.0 & 22.0 & 19.8 & 19.9 & & 84 & 61 & 110 & 128 \\
\hline September & 15.3 & 16.5 & 17.3 & 15.4 & & 138 & 67 & 82 & 130 \\
\hline October & 12.7 & 10.8 & 9.7 & 10.7 & & 57 & 262 & 115 & 118 \\
\hline Mean & 17.0 & 17.3 & 16.7 & 15.9 & Sum & 566 & 781 & 679 & 792 \\
\hline
\end{tabular}

Table 4. Plant spacing parameters.

\begin{tabular}{|c|c|c|c|c|c|c|c|c|c|}
\hline Year & $\begin{array}{l}\text { Planting } \\
\text { speed }\end{array}$ & $\begin{array}{l}\text { MD } \\
(\mathrm{cm})\end{array}$ & $\begin{array}{l}\text { SDALL } \\
\text { (cm) }\end{array}$ & $\begin{array}{l}\text { SDREF } \\
(\mathrm{cm})\end{array}$ & $\begin{array}{l}\text { MUI } \\
(\%)\end{array}$ & $\begin{array}{l}\text { MII } \\
(\%)\end{array}$ & $\begin{array}{l}\text { SS } \\
(\%)\end{array}$ & $\begin{array}{l}\text { DS } \\
(\%)\end{array}$ & $\begin{array}{l}\text { TS } \\
(\%)\end{array}$ \\
\hline 2013 & $\begin{array}{c}7 \mathrm{~km} / \mathrm{h} \\
9 \mathrm{~km} / \mathrm{h} \\
11 \mathrm{~km} / \mathrm{h}\end{array}$ & $\begin{array}{l}17.0 \pm 0.2^{\mathrm{a}} \\
17.8 \pm 0.3^{\mathrm{b}} \\
18.9 \pm 0.4^{\mathrm{c}}\end{array}$ & $\begin{array}{l}5.9 \pm 0.2^{\mathrm{a}} \\
7.7 \pm 0.3^{\mathrm{b}} \\
8.9 \pm 0.4^{\mathrm{c}}\end{array}$ & $\begin{array}{l}3.4 \pm 0.1^{\mathrm{a}} \\
3.9 \pm 0.2^{\mathrm{b}} \\
4.2 \pm 0.2^{\mathrm{b}}\end{array}$ & $\begin{array}{l}4.4 \pm 1.1^{\mathrm{a}} \\
5.7 \pm 1.1^{\mathrm{a}} \\
8.4 \pm 1.4^{\mathrm{b}}\end{array}$ & $\begin{array}{c}9.7 \pm 1.7^{\mathrm{a}} \\
12.9 \pm 1.1^{\mathrm{b}} \\
20.1 \pm 2.2^{\mathrm{c}}\end{array}$ & $\begin{array}{c}9.6 \pm 1.7^{\mathrm{a}} \\
11.9 \pm 1.0^{\mathrm{a}} \\
17.1 \pm 1.8^{\mathrm{b}}\end{array}$ & $\begin{array}{l}0.1 \pm 0.1^{\mathrm{a}} \\
0.7 \pm 0.2^{\mathrm{a}} \\
2.4 \pm 0.7^{\mathrm{b}}\end{array}$ & $\begin{array}{l}0.0 \pm 0.0^{\mathrm{a}} \\
0.3 \pm 0.2^{\mathrm{a}} \\
0.6 \pm 0.4^{\mathrm{a}}\end{array}$ \\
\hline 2015 & $\begin{array}{c}7 \mathrm{~km} / \mathrm{h} \\
9 \mathrm{~km} / \mathrm{h} \\
11 \mathrm{~km} / \mathrm{h}\end{array}$ & $\begin{array}{l}16.7 \pm 0.2^{\mathrm{a}} \\
17.7 \pm 0.2^{\mathrm{b}} \\
18.4 \pm 0.3^{\mathrm{c}}\end{array}$ & $\begin{array}{l}5.1 \pm 0.3^{a} \\
6.8 \pm 0.3^{b} \\
8.2 \pm 0.5^{c}\end{array}$ & $\begin{array}{l}3.2 \pm 0.1^{\mathrm{a}} \\
3.5 \pm 0.1^{\mathrm{b}} \\
3.8 \pm 0.1^{\mathrm{c}}\end{array}$ & $\begin{array}{l}2.4 \pm 0.7^{\mathrm{a}} \\
3.7 \pm 0.6^{\mathrm{a}} \\
6.8 \pm 1.2^{\mathrm{b}}\end{array}$ & $\begin{array}{c}6.3 \pm 1.0^{\mathrm{a}} \\
11.2 \pm 0.8^{\mathrm{b}} \\
16.0 \pm 1.0^{\mathrm{c}}\end{array}$ & $\begin{array}{c}6.0 \pm 1.0^{\mathrm{a}} \\
10.3 \pm 0.8^{\mathrm{b}} \\
14.4 \pm 1.1^{\mathrm{c}}\end{array}$ & $\begin{array}{c}0.3 \pm 0.2^{\mathrm{a}} \\
0.8 \pm 0.3^{\mathrm{ab}} \\
1.4 \pm 0.3^{\mathrm{b}}\end{array}$ & $\begin{array}{l}0.0 \pm 0.0^{\mathrm{a}} \\
0.1 \pm 0.2^{\mathrm{a}} \\
0.2 \pm 0.1^{\mathrm{a}}\end{array}$ \\
\hline 2016 & $\begin{array}{c}7 \mathrm{~km} / \mathrm{h} \\
9 \mathrm{~km} / \mathrm{h} \\
11 \mathrm{~km} / \mathrm{h}\end{array}$ & $\begin{array}{l}17.3 \pm 0.2^{\mathrm{a}} \\
18.0 \pm 0.3^{\mathrm{b}} \\
18.7 \pm 0.3^{\mathrm{c}}\end{array}$ & $\begin{array}{l}6.1 \pm 0.2^{\mathrm{a}} \\
7.7 \pm 0.3^{\mathrm{b}} \\
8.8 \pm 0.3^{\mathrm{c}}\end{array}$ & $\begin{array}{l}2.8 \pm 0.1^{\mathrm{a}} \\
3.3 \pm 0.1^{\mathrm{b}} \\
3.9 \pm 0.2^{\mathrm{c}}\end{array}$ & $\begin{array}{l}2.4 \pm 0.4^{\mathrm{a}} \\
2.5 \pm 0.6^{\mathrm{a}} \\
4.6 \pm 0.8^{\mathrm{b}}\end{array}$ & $\begin{array}{l}10.3 \pm 0.9^{\mathrm{a}} \\
14.2 \pm 1.1^{\mathrm{b}} \\
17.5 \pm 1.5^{\mathrm{c}}\end{array}$ & $\begin{array}{c}9.1 \pm 0.7^{\mathrm{a}} \\
12.5 \pm 1.0^{\mathrm{b}} \\
14.4 \pm 1.2^{\mathrm{b}}\end{array}$ & $\begin{array}{l}1.2 \pm 0.3^{\mathrm{a}} \\
1.6 \pm 0.5^{\mathrm{a}} \\
2.6 \pm 0.6^{\mathrm{a}}\end{array}$ & $\begin{array}{c}0.0 \pm 0.0^{\mathrm{a}} \\
0.1 \pm 0.1^{\mathrm{ab}} \\
0.5 \pm 0.2^{\mathrm{b}}\end{array}$ \\
\hline
\end{tabular}

a-c Different letters in the same column and the same year represent significant difference according to Duncan's test ( $\mathrm{P}<0.05)$. MD, mean distance; SDALL, st. deviation (all distances); STREF, st. deviation (singles); MUI, Multiple Index; MII, Miss Index; SS, single skips; DS, double skips; TS, triple skips. 
standard deviation is influenced by miss and double places between the plants in a row, the standard deviation from the distances which only included singles $(0.5$ to $1.5 \times$ the theoretical spacing) was calculated. The standard deviation including singles in 2015 and 2016 significantly increased with the increased planting speed, while in 2013 at the planting speed $7 \mathrm{~km} / \mathrm{h}$ it was significantly lower than at the other two planting speeds. In this case the standard deviation was also lower than at the standard deviation with all distances. The Multiple Index at the planting speed of 11 $\mathrm{km} / \mathrm{h}$ was significantly higher than at the planting speeds 7 and 9 $\mathrm{km} / \mathrm{h}$ in all years of the experiment. The Miss Index also significantly increased with increased planting speed. In 2015 and 2016 there were significantly fewer single skips at the planting speed 7 $\mathrm{km} / \mathrm{h}$ than at the planting speeds 9 and $11 \mathrm{~km} / \mathrm{h}$, while in 2013 there were significantly fewer single skips at the planting speeds 7 and $9 \mathrm{~km} / \mathrm{h}$ than at the planting speed $11 \mathrm{~km} / \mathrm{h}$. In 2013 and 2015, there were more double skips at the planting speed $11 \mathrm{~km} / \mathrm{h}$ than at the planting speed $7 \mathrm{~km} / \mathrm{h}$. There were no differences between the planting speeds in regard to triple skips.

The Quality of Feed Index in the experiment in 2015 and 2016 significantly decreased with increased planting speed, while in 2013 the planting speed at $11 \mathrm{~km} / \mathrm{h}$ was significantly lower than at the other two planting speeds (Table 5). The precision $\mathrm{C}$ in the experiment significantly increased with the planting speed increase from 7 to $11 \mathrm{~km} / \mathrm{h}$. The density of plants per hectare significantly decreased with increased planting speed in all years of the experiment.

\section{Silage yield}

In general, the silage yields in 2015 were lower than in 2016 (Table 6). Similarly, the dry matter yields in 2015 ranged from 19.2 to $20.3 \mathrm{t} / \mathrm{ha}$, while a year later they ranged from 25.5 to $27.4 \mathrm{t} / \mathrm{ha}$. The results for the year 2015 show that both the silage yield per plant and dry matter yield per plant was significantly higher at the planting speed $11 \mathrm{~km} / \mathrm{h}$ than at the planting speed $7 \mathrm{~km} / \mathrm{h}$. A year later, the silage yield per plant and dry matter yield per plant at the planting speeds $9 \mathrm{~km} / \mathrm{h}$ and $11 \mathrm{~km} / \mathrm{h}$ was significantly higher than at the planting speed $7 \mathrm{~km} / \mathrm{h}$. With regard to dry matter, different results were obtained in both years of the experiment. In 2015, the planting speed $11 \mathrm{~km} / \mathrm{h}$ produced a higher percentage of dry matter than the planting speed $9 \mathrm{~km} / \mathrm{h}$, while a year later the percentage of dry matter at the planting speed $9 \mathrm{~km} / \mathrm{h}$ was significantly higher than at the planting speed $11 \mathrm{~km} / \mathrm{h}$. The percentage of dry matter in 2016 was higher than in the year 2015.

\section{Grain yield and ear parameters}

No significant differences appeared in grain yield and grain moisture at different planting speeds (Table 6). In contrast, significant differences appeared in the grain yield per plant. In 2015, the grain yield per plant at the planting speed $11 \mathrm{~km} / \mathrm{h}$ was significantly higher than at the planting speed $7 \mathrm{~km} / \mathrm{h}$, while a year later the grain yield per plant at the planting speed $11 \mathrm{~km} / \mathrm{h}$ was significantly higher than at other two planting speeds. A similar scenario also emerged when individual ears and their parameters (kernel mass per ear, total ear mass, individual kernel mass, etc.) were analysed. The kernel mass per ear and the total ear mass were significantly higher at the planting speed $11 \mathrm{~km} / \mathrm{h}$ than at the speeds 7 and 9 $\mathrm{km} / \mathrm{h}$ (2015), or than at the speed $7 \mathrm{~km} / \mathrm{h}$ (2016) (Table 7). The cob mass was at the planting speed $11 \mathrm{~km} / \mathrm{h}$ significantly higher than at the planting speed 7 and $9 \mathrm{~km} / \mathrm{h}$ in both years of the experiment. Planting speed did not significantly affect the number of kernel rows per ear. Significant differences between planting speeds emerged in the number of kernels per ear. In 2015, the number of kernels per ear at the planting speeds 9 and $11 \mathrm{~km} / \mathrm{h}$ was significantly higher than at the planting speed $7 \mathrm{~km} / \mathrm{h}$, while there were no differences in 2016. The individual kernel mass at the planting

Table 5. Quality of Feed Index, precision C and plant density.

\begin{tabular}{|c|c|c|c|c|}
\hline Year & Planting speed & FI $(\%)$ & C (\%) & PD (plants/ha) \\
\hline 2013 & $\begin{array}{c}7 \mathrm{~km} / \mathrm{h} \\
9 \mathrm{~km} / \mathrm{h} \\
11 \mathrm{~km} / \mathrm{h}\end{array}$ & $\begin{array}{l}85.9 \pm 2.6^{\mathrm{b}} \\
81.4 \pm 2.0^{\mathrm{b}} \\
71.4 \pm 3.3^{\mathrm{a}}\end{array}$ & $\begin{array}{l}20.5 \pm 0.8^{a} \\
23.5 \pm 0.7^{b} \\
25.2 \pm 1.3^{b}\end{array}$ & $\begin{array}{l}79,111 \pm 1006^{\mathrm{c}} \\
75,111 \pm 1047^{\mathrm{b}} \\
70,889 \pm 1317^{\mathrm{a}}\end{array}$ \\
\hline 2015 & $\begin{array}{c}7 \mathrm{~km} / \mathrm{h} \\
9 \mathrm{~km} / \mathrm{h} \\
11 \mathrm{~km} / \mathrm{h}\end{array}$ & $\begin{array}{l}91.3 \pm 1.2^{\mathrm{c}} \\
85.1 \pm 0.9^{\mathrm{b}} \\
77.2 \pm 1.2^{\mathrm{a}}\end{array}$ & $\begin{array}{l}19.6 \pm 0.6^{\mathrm{a}} \\
21.4 \pm 0.5^{\mathrm{b}} \\
23.0 \pm 0.8^{\mathrm{c}}\end{array}$ & $\begin{array}{l}80,317 \pm 1131^{\mathrm{c}} \\
75,667 \pm 1018^{\mathrm{b}} \\
72,464 \pm 1061^{\mathrm{a}}\end{array}$ \\
\hline 2016 & $\begin{array}{c}7 \mathrm{~km} / \mathrm{h} \\
9 \mathrm{~km} / \mathrm{h} \\
11 \mathrm{~km} / \mathrm{h} \\
\end{array}$ & $\begin{array}{l}87.2 \pm 1.2^{\mathrm{c}} \\
83.3 \pm 1.1^{\mathrm{b}} \\
77.8 \pm 1.4^{\mathrm{a}}\end{array}$ & $\begin{array}{l}16.7 \pm 0.6^{\mathrm{a}} \\
20.0 \pm 0.7^{\mathrm{b}} \\
23.3 \pm 0.8^{\mathrm{c}}\end{array}$ & $\begin{array}{l}78,071 \pm 1008^{\mathrm{c}} \\
74,083 \pm 1055^{\mathrm{b}} \\
70,701 \pm 1286^{\mathrm{a}}\end{array}$ \\
\hline
\end{tabular}

a-cDifferent letters in the same column and the same year represent significant difference according to Duncan's test $(\mathrm{P}<0.05)$. FI, Quality of Feed Index; C, precision C; PD, plant density.

Table 6. Silage and grain yield parameters.

\begin{tabular}{|c|c|c|c|c|c|c|c|c|c|}
\hline Year & $\begin{array}{c}\text { Planting } \\
\text { speed }\end{array}$ & $\begin{array}{c}\text { SY } \\
\text { (t/ha) }\end{array}$ & $\begin{array}{l}\text { DM } \\
(\%)\end{array}$ & $\begin{array}{l}\text { DMY } \\
\text { (t/ha) }\end{array}$ & $\begin{array}{l}\text { SYP } \\
(\mathrm{kg})\end{array}$ & $\begin{array}{l}\text { DMYP } \\
(\mathrm{kg})\end{array}$ & $\begin{array}{c}\text { GY } \\
\text { (t/ha) }\end{array}$ & $\begin{array}{l}\text { GM } \\
(\%)\end{array}$ & $\begin{array}{l}\text { GYP } \\
(\mathrm{kg})\end{array}$ \\
\hline 2015 & $\begin{array}{c}7 \mathrm{~km} / \mathrm{h} \\
9 \mathrm{~km} / \mathrm{h} \\
11 \mathrm{~km} / \mathrm{h}\end{array}$ & $\begin{array}{l}44.3 \pm 1.6^{\mathrm{a}} \\
44.3 \pm 1.4^{\mathrm{a}} \\
44.6 \pm 1.6^{\mathrm{a}}\end{array}$ & $\begin{array}{c}45.1 \pm 1.0^{\mathrm{ab}} \\
43.3 \pm 1.0^{\mathrm{a}} \\
45.6 \pm 1.0^{\mathrm{b}}\end{array}$ & $\begin{array}{l}20.0 \pm 0.8^{a} \\
19.2 \pm 0.7^{a} \\
20.3 \pm 1.0^{a}\end{array}$ & $\begin{array}{c}0.551 \pm 0.021^{\mathrm{a}} \\
0.585 \pm 0.022^{\mathrm{ab}} \\
0.608 \pm 0.018^{\mathrm{b}}\end{array}$ & $\begin{array}{c}0.249 \pm 0.011^{\mathrm{a}} \\
0.254 \pm 0.010^{\mathrm{ab}} \\
0.277 \pm 0.007^{\mathrm{b}}\end{array}$ & $\begin{array}{l}11.9 \pm 0.4^{\mathrm{a}} \\
12.0 \pm 0.3^{\mathrm{a}} \\
11.9 \pm 0.5^{\mathrm{a}}\end{array}$ & $\begin{array}{l}24.8 \pm 0.4^{\mathrm{a}} \\
25.8 \pm 0.4^{\mathrm{a}} \\
24.7 \pm 0.2^{\mathrm{a}}\end{array}$ & $\begin{array}{c}0.148 \pm 0.005^{\mathrm{a}} \\
0.159 \pm 0.004^{\mathrm{ab}} \\
0.162 \pm 0.005^{\mathrm{b}}\end{array}$ \\
\hline 2016 & $\begin{array}{c}7 \mathrm{~km} / \mathrm{h} \\
9 \mathrm{~km} / \mathrm{h} \\
11 \mathrm{~km} / \mathrm{h}\end{array}$ & $\begin{array}{l}52.8 \pm 1.5^{\mathrm{a}} \\
55.3 \pm 1.8^{\mathrm{a}} \\
53.9 \pm 1.9^{\mathrm{a}}\end{array}$ & $\begin{array}{c}49.2 \pm 0.4^{\mathrm{ab}} \\
49.6 \pm 1.1^{\mathrm{b}} \\
47.3 \pm 0.5^{\mathrm{a}}\end{array}$ & $\begin{array}{l}26.0 \pm 0.8^{a} \\
27.4 \pm 1.1^{a} \\
25.5 \pm 0.9^{a}\end{array}$ & $\begin{array}{l}0.676 \pm 0.025^{\mathrm{a}} \\
0.746 \pm 0.025^{\mathrm{b}} \\
0.762 \pm 0.023^{\mathrm{b}}\end{array}$ & $\begin{array}{l}0.333 \pm 0.010^{\mathrm{a}} \\
0.370 \pm 0.011^{\mathrm{b}} \\
0.361 \pm 0.011^{\mathrm{b}}\end{array}$ & $\begin{array}{l}12.3 \pm 0.4^{\mathrm{a}} \\
12.4 \pm 0.3^{\mathrm{a}} \\
13.0 \pm 0.3^{\mathrm{a}}\end{array}$ & $\begin{array}{l}24.9 \pm 0.4^{\mathrm{a}} \\
24.9 \pm 0.4^{\mathrm{a}} \\
25.3 \pm 0.4^{\mathrm{a}}\end{array}$ & $\begin{array}{l}0.158 \pm 0.007^{\mathrm{a}} \\
0.167 \pm 0.006^{\mathrm{a}} \\
0.184 \pm 0.007^{\mathrm{b}}\end{array}$ \\
\hline
\end{tabular}

Different letters in the same column and the same year represent significant difference according to Duncan's test $(\mathrm{P}<0.05)$. SY $=$ silage yield, DM $=$ dry matter, DMY $=$ dry matter yield, SYP $=$ silage yield per plant, $\mathrm{DMYP}=$ dry matter yield per plant, GY = grain yield, $\mathrm{GM}=$ grain moisture, $\mathrm{GYP}=$ grain yield per plant 
speed $11 \mathrm{~km} / \mathrm{h}$ was also significantly higher than at the planting speed $9 \mathrm{~km} / \mathrm{h}(2015)$ and the planting speed $7 \mathrm{~km} / \mathrm{h}(2016)$.

\section{Correlations}

The correlations between variables according to Pearson were calculated. According to Roemer - Orphal's scale (Vasilj, 2000), a strong positive correlation $(\mathrm{r}=0.5-0.75)$ was found between the planting speed and the following variables: the standard deviation (all distances), the standard deviation (singles), the precision $\mathrm{C}$, the Miss Index, and the single skips (Table 8 ). The correlation between the planting speed and the Miss Index $(\mathrm{r}=0.65)$ was stronger than between the planting speed and the Multiple Index $(\mathrm{r}=0.42)$. A strong negative correlation $(\mathrm{r}=-0.67)$ appeared between the planting speed and the Quality of Feed Index, as well as between the planting speed and the plant density $(\mathrm{r}=-0.61)$. A strong positive correlation was observed between the standard deviation (all distances) and the following variables: the standard deviation (singles), the precision $\mathrm{C}$, the Multiple Index, the Miss Index, the single, double. and the triple skips. Also, the linear correlation between the standard deviation and the Miss Index ( $\mathrm{r}=0.74)$ was stronger than between the standard deviation and the Multiple Index $(r=0.52)$. This suggests that the miss places between plants exert greater influence on the standard deviation than the double places. A negative correlation was observed between the standard deviation (all distances) and the plant density $(\mathrm{r}=-0.74)$. This means that the density of plants decreases with increased standard deviation. Between the standard deviation (all distances) and the Quality of Feed Index, a very strong negative correlation $(\mathrm{r}=-$ $0.77)$ appeared. A completely positive correlation $(\mathrm{r}=1.0)$ was observed between the standard deviation (singles) and the precision (C), which was expected, as the precision $\mathrm{C}$ is calculated from the data on standard deviation (singles). A strong positive correlation was observed between the standard deviation (singles) and the Multiple Index $(\mathrm{r}=0.55)$, and between the precision $\mathrm{C}$ and the Multiple Index $(r=0.56)$. According to Roemer-Orphal's scale, a very strong correlation means that the correlation coefficient is between 0.75 and 0.90 . A very strong negative correlation was observed between the plant density and the Miss Index $(\mathrm{r}=-0.85)$, which means that the plant density decreases with an increased

Table 7. Ear parameters.

\begin{tabular}{|c|c|c|c|c|c|c|c|}
\hline Year & $\begin{array}{l}\text { Planting } \\
\text { speed }\end{array}$ & $\begin{array}{l}\text { KME } \\
(\mathrm{g})\end{array}$ & $\begin{array}{l}\text { TEM } \\
(\mathrm{g})\end{array}$ & $\begin{array}{l}\text { CM } \\
\text { (g) }\end{array}$ & $\begin{array}{c}\text { NKR } \\
(-)\end{array}$ & $\begin{array}{l}\text { NKE } \\
(-)\end{array}$ & $\begin{array}{l}\text { IKM } \\
(\mathrm{mg})\end{array}$ \\
\hline 2015 & $\begin{array}{c}7 \mathrm{~km} / \mathrm{h} \\
9 \mathrm{~km} / \mathrm{h} \\
11 \mathrm{~km} / \mathrm{h}\end{array}$ & $\begin{array}{l}151.0 \pm 4.0^{\mathrm{a}} \\
159.9 \pm 3.0^{\mathrm{a}} \\
170.6 \pm 3.6^{\mathrm{b}}\end{array}$ & $\begin{array}{l}169.4 \pm 4.3^{\mathrm{a}} \\
178.8 \pm 3.3^{\mathrm{a}} \\
190.9 \pm 3.9^{\mathrm{b}}\end{array}$ & $\begin{array}{l}18.4 \pm 0.4^{\mathrm{a}} \\
18.9 \pm 0.4^{\mathrm{a}} \\
20.3 \pm 0.4^{\mathrm{b}}\end{array}$ & $\begin{array}{l}14.4 \pm 0.2^{\mathrm{a}} \\
14.8 \pm 0.1^{\mathrm{a}} \\
14.6 \pm 0.2^{\mathrm{a}}\end{array}$ & $\begin{array}{c}372.4 \pm 10.1^{\mathrm{a}} \\
403.9 \pm 6.8^{\mathrm{b}} \\
412.2 \pm 8.9^{\mathrm{b}}\end{array}$ & $\begin{array}{c}405.9 \pm 5.3^{\mathrm{ab}} \\
395.9 \pm 6.5^{\mathrm{a}} \\
414.1 \pm 4.5^{\mathrm{b}}\end{array}$ \\
\hline 2016 & $\begin{array}{c}7 \mathrm{~km} / \mathrm{h} \\
9 \mathrm{~km} / \mathrm{h} \\
11 \mathrm{~km} / \mathrm{h}\end{array}$ & $\begin{array}{c}187.1 \pm 3.5^{\mathrm{a}} \\
191.7 \pm 3.2^{\mathrm{ab}} \\
199.0 \pm 3.5^{\mathrm{b}}\end{array}$ & $\begin{array}{c}207.9 \pm 3.8^{a} \\
212.5 \pm 3.5^{a b} \\
221.1 \pm 3.9^{b}\end{array}$ & $\begin{array}{l}20.7 \pm 0.4^{a} \\
20.8 \pm 0.4^{a} \\
22.0 \pm 0.4^{b}\end{array}$ & $\begin{array}{l}15.0 \pm 0.1^{\mathrm{a}} \\
15.1 \pm 0.1^{\mathrm{a}} \\
15.1 \pm 0.1^{\mathrm{a}}\end{array}$ & $\begin{array}{l}485.7 \pm 7.0^{\mathrm{a}} \\
487.7 \pm 6.8^{\mathrm{a}} \\
498.1 \pm 7.2^{\mathrm{a}}\end{array}$ & $\begin{array}{c}385.2 \pm 3.5^{\mathrm{a}} \\
393.1 \pm 3.8^{\mathrm{ab}} \\
399.5 \pm 3.8^{\mathrm{b}}\end{array}$ \\
\hline
\end{tabular}

a-bifferent letters in the same column and the same year represent significant difference according to Duncan's test ( $\mathrm{P}<0.05)$. KME, kernel mass per ear; TEM, total ear mass; CM, cob mass; NKR, number of kernel rows per ear; NKE, number of kernels per ear; IKM, individual kernel mass.

Table 8. Pearson product moment correlations between each pair of variables.

\begin{tabular}{|c|c|c|c|c|c|c|c|c|c|c|c|}
\hline & PS & SDALL & SDREF & C & PD & MUI & MII & SS & DS & TS & FI \\
\hline PS & & $\begin{array}{c}0.64 \\
*\end{array}$ & $\begin{array}{c}0.58 \\
*\end{array}$ & $\begin{array}{c}0.59 \\
*\end{array}$ & $\begin{array}{c}-0.61 \\
*\end{array}$ & $\begin{array}{c}0.42 \\
*\end{array}$ & $\begin{array}{c}0.65 \\
*\end{array}$ & $\begin{array}{c}0.59 \\
*\end{array}$ & $\begin{array}{c}0.41 \\
*\end{array}$ & $\begin{array}{c}0.27 \\
*\end{array}$ & $\begin{array}{c}-0.67 \\
*\end{array}$ \\
\hline SDALL & $\begin{array}{c}0.64 \\
*\end{array}$ & & $\begin{array}{c}0.53 \\
*\end{array}$ & $\begin{array}{c}0.53 \\
*\end{array}$ & $\begin{array}{c}-0.74 \\
*\end{array}$ & $\begin{array}{c}0.52 \\
*\end{array}$ & $\begin{array}{c}0.74 \\
*\end{array}$ & $\begin{array}{c}0.59 \\
*\end{array}$ & $\begin{array}{c}0.60 \\
*\end{array}$ & $\begin{array}{c}0.59 \\
*\end{array}$ & $\begin{array}{c}-0.77 \\
*\end{array}$ \\
\hline SDREF & $\begin{array}{c}0.58 \\
*\end{array}$ & $\begin{array}{c}0.53 \\
*\end{array}$ & $x_{2}$ & $\begin{array}{c}1.00 \\
*\end{array}$ & $\begin{array}{c}-0.32 \\
*\end{array}$ & $\begin{array}{c}0.56 \\
*\end{array}$ & $\begin{array}{c}0.46 \\
*\end{array}$ & $\begin{array}{c}0.44 \\
*\end{array}$ & $\begin{array}{c}0.20 \\
\text { ns }\end{array}$ & $\begin{array}{c}0.21 \\
*\end{array}$ & $\begin{array}{c}-0.59 \\
*\end{array}$ \\
\hline C & $\begin{array}{c}0.59 \\
* \\
\end{array}$ & $\begin{array}{c}0.53 \\
*\end{array}$ & $\begin{array}{c}1.00 \\
*\end{array}$ & & $\begin{array}{c}-0.32 \\
* \\
\end{array}$ & $\begin{array}{c}0.56 \\
* \\
\end{array}$ & $\begin{array}{c}0.46 \\
* \\
\end{array}$ & $\begin{array}{c}0.43 \\
* \\
\end{array}$ & $\begin{array}{c}0.20 \\
\text { ns }\end{array}$ & $\begin{array}{c}0.21 \\
*\end{array}$ & $\begin{array}{c}-0.59 \\
*\end{array}$ \\
\hline PD & $\begin{array}{c}-0.61 \\
*\end{array}$ & $\begin{array}{c}-0.74 \\
*\end{array}$ & $\begin{array}{c}-0.32 \\
*\end{array}$ & $\begin{array}{c}-0.32 \\
*\end{array}$ & & $\begin{array}{c}-0.11 \\
\mathrm{~ns}\end{array}$ & $\begin{array}{c}-0.85 \\
*\end{array}$ & $\begin{array}{c}-0.73 \\
*\end{array}$ & $\begin{array}{c}-0.57 \\
*\end{array}$ & $\begin{array}{c}-0.45 \\
*\end{array}$ & $\begin{array}{c}0.67 \\
*\end{array}$ \\
\hline MUI & $\begin{array}{c}0.42 \\
*\end{array}$ & $\begin{array}{c}0.52 \\
*\end{array}$ & $\begin{array}{c}0.55 \\
*\end{array}$ & $\begin{array}{c}0.56 \\
*\end{array}$ & $\begin{array}{c}-0.11 \\
\mathrm{~ns}\end{array}$ & & $\begin{array}{c}0.40 \\
*\end{array}$ & $\begin{array}{c}0.39 \\
*\end{array}$ & $\begin{array}{c}0.13 \\
\text { ns }\end{array}$ & $\begin{array}{c}0.21 \\
*\end{array}$ & $\begin{array}{c}-0.74 \\
*\end{array}$ \\
\hline MII & $\begin{array}{c}0.65 \\
*\end{array}$ & $\begin{array}{c}0.74 \\
*\end{array}$ & $\begin{array}{c}0.46 \\
*\end{array}$ & $\begin{array}{c}0.46 \\
*\end{array}$ & $\begin{array}{c}-0.85 \\
*\end{array}$ & $\begin{array}{c}0.40 \\
*\end{array}$ & & $\begin{array}{c}0.94 \\
*\end{array}$ & $\begin{array}{c}0.51 \\
*\end{array}$ & $\begin{array}{c}0.34 \\
*\end{array}$ & $\begin{array}{c}-0.91 \\
*\end{array}$ \\
\hline SS & $\begin{array}{c}0.59 \\
*\end{array}$ & $\begin{array}{c}0.59 \\
*\end{array}$ & $\begin{array}{c}0.44 \\
*\end{array}$ & $\begin{array}{c}0.43 \\
*\end{array}$ & $\begin{array}{c}-0.73 \\
*\end{array}$ & $\begin{array}{c}0.39 \\
*\end{array}$ & $\begin{array}{c}0.94 \\
*\end{array}$ & & $\begin{array}{c}0.27 \\
*\end{array}$ & $\begin{array}{c}0.23 \\
*\end{array}$ & $\begin{array}{c}-0.87 \\
*\end{array}$ \\
\hline DS & $\begin{array}{c}0.41 \\
*\end{array}$ & $\begin{array}{c}0.60 \\
*\end{array}$ & $\begin{array}{c}0.20 \\
n s\end{array}$ & $\begin{array}{c}0.20 \\
\text { ns }\end{array}$ & $\begin{array}{c}-0.57 \\
*\end{array}$ & $\begin{array}{c}0.13 \\
n s\end{array}$ & $\begin{array}{c}0.51 \\
*\end{array}$ & $\begin{array}{c}0.27 \\
*\end{array}$ & & $\begin{array}{c}0.11 \\
\text { ns }\end{array}$ & $\begin{array}{c}-0.43 \\
*\end{array}$ \\
\hline TS & $\begin{array}{c}0.27 \\
*\end{array}$ & $\begin{array}{c}0.59 \\
*\end{array}$ & $\begin{array}{c}0.21 \\
*\end{array}$ & $\begin{array}{c}0.21 \\
*\end{array}$ & $\begin{array}{c}-0.45 \\
*\end{array}$ & $\begin{array}{c}0.21 \\
*\end{array}$ & $\begin{array}{c}0.34 \\
*\end{array}$ & $\begin{array}{c}0.23 \\
*\end{array}$ & $\begin{array}{c}0.11 \\
\text { ns }\end{array}$ & & $\begin{array}{c}-0.34 \\
*\end{array}$ \\
\hline $\mathrm{FI}$ & $\begin{array}{c}-0.67 \\
*\end{array}$ & $\begin{array}{c}-0.77 \\
*\end{array}$ & $\begin{array}{c}-0.59 \\
*\end{array}$ & $\begin{array}{c}-0.59 \\
*\end{array}$ & $\begin{array}{c}0.67 \\
*\end{array}$ & $\begin{array}{c}-0.74 \\
*\end{array}$ & $\begin{array}{c}-0.91 \\
*\end{array}$ & $\begin{array}{c}-0.87 \\
*\end{array}$ & $\begin{array}{c}-0.43 \\
*\end{array}$ & $\begin{array}{c}-0.34 \\
*\end{array}$ & \\
\hline
\end{tabular}

${ }^{*} \mathrm{P}<0.05$. ns, not significant; PS, planting speed; SDALL, st. deviation (all distances); SDREF, st. deviation (singles); C, precision C; PD, plant density; MUI, Multiple Index; MII, Miss Index; SS, single skips; DS, double skips; TS, triple skips; FI, Quality of Feed Index. 
Miss Index. This is also confirmed by a strong negative correlation between the plant density and the single skips $(\mathrm{r}=-0.73)$, as well as between the plant density and the double skips $(\mathrm{r}=-0.56)$. A very strong correlation was observed between the Miss Index and the single skips $(\mathrm{r}=0.94)$. This suggests that single skips exert greater influence on Miss Index than double skips $(\mathrm{r}=0.51)$. A completely negative correlation was established between the Quality of Feed Index and the Miss Index $(r=-0.91)$. A very strong negative correlation was also observed between the Quality of Feed Index and the following variables: the single skips $(\mathrm{r}=-$ $0.87)$, and the standard deviation at all distances $(r=-0.77)$. A strong negative correlation was observed between the Quality of Feed Index and the following variables: the planting speed, the standard deviation - singles, the precision $\mathrm{C}$, and the Multiple Index. A strong positive correlation was also observed between the Quality of Feed Index and the plant density.

The fuel consumption per hectare and energy requirement at the planting speeds 9 and $11 \mathrm{~km} / \mathrm{h}$ was significantly lower than at the planting speed of $7 \mathrm{~km} / \mathrm{h}$ (Table 9 ).

\section{Discussion}

Results regarding plant distances show that the standard deviation in our experiment was certainly lower than the one recorded by Nielsen (2001), who reported that as much as $60 \%$ of the experimental locations had standard deviation between 10.2 and 12.7 $\mathrm{cm}$, with the permissible level for standard deviation of $5 \mathrm{~cm}$. We approached this value most closely at the planting speed $7 \mathrm{~km} / \mathrm{h}$. In our experiment it did not exceed $9.0 \mathrm{~cm}$ even at the highest planting speed $(11 \mathrm{~km} / \mathrm{h})$, which points to the fact that the settings on our planter were correct, both with regard to the air pressure on seed plates and also planting depth, and consequently the planting was performed more accurately. We believe that higher Multiple Index at $11 \mathrm{~km} / \mathrm{h}$ appeared because at this planting speed two or more seeds were sucked and not removed from the hole on the seeding plate. Increased Miss Index with increasing plant speed happened because the seeds could not be sucked to every hole on the seed plate. As a result, some holes on the seed plate did not have any seeds. This was also shown during the planting by the results of density on the planter computer, which received a signal from the photocell for each row and is the most probable cause of the Miss Index value. This can be ameliorated with special fingers on the planter, which press seeds in a planting row (Staggenborg et al., 2004). The Miss Index was on average higher than the Multiple Index, which means that it had greater influence on the plant spacing variability. In general, single skips were most frequent, while the least frequent were triple skips.

The Quality of Feed Index is a measure of how often the spac-

Table 9. Fuel consumption and energy requirement at planting.

\begin{tabular}{lcc}
$\begin{array}{l}\text { Planting } \\
\text { speed }\end{array}$ & $\begin{array}{c}\text { Fuel consumption } \\
(\text { L/ha) }\end{array}$ & $\begin{array}{c}\text { Energy requirement } \\
\text { (MJ/ha) }\end{array}$ \\
$7 \mathrm{~km} / \mathrm{h}$ & $4.6 \pm 0.1^{\mathrm{b}}$ & $163.3 \pm 4.6^{\mathrm{b}}$ \\
$9 \mathrm{~km} / \mathrm{h}$ & $4.2 \pm 0.1^{\mathrm{a}}$ & $146.2 \pm 4.7^{\mathrm{a}}$ \\
\hline $11 \mathrm{~km} / \mathrm{h}$ & $3.9 \pm 0.2^{\mathrm{a}}$ & $139.0 \pm 6.4^{\mathrm{a}}$ \\
\hline
\end{tabular}

${ }^{\text {a-b } D i f f e r e n t ~ l e t t e r s ~ i n ~ t h e ~ s a m e ~ c o l u m n ~ r e p r e s e n t ~ s i g n i f i c a n t ~ d i f f e r e n c e ~ a c c o r d i n g ~ t o ~ D u n c a n ' s ~ t e s t ~}$ $(\mathrm{P}<0.05)$. ings were close to the theoretical spacing $16.5 \mathrm{~cm}$. It comprises those distances between plants which are defined as singles. The Miss Index and the Multiple Index affect the quality of the feed index, therefore it was consequently the lowest at the planting speed $11 \mathrm{~km} / \mathrm{h}$. The results are congruent with those of Elmore (2002), who recorded lower feed index quality at the planting speed $9.7 \mathrm{~km} / \mathrm{h}$ than at the planting speeds 3.2 and $6.4 \mathrm{~km} / \mathrm{h}$. The Quality of Feed Index at 15 locations in his experiment was on average between 71.0 and $88.1 \%$, which is comparable to the results of this study. Elmore (2002) worked with lower planting speeds than the ones used in this study, and for this reason we suppose our planter was more precise.

The precision $\mathrm{C}$ indicates variability within the desired distances (0.5-1.5 $\times$ the theoretical distance) and is not affected by distances, such as double and miss places between plants. Kachman and Smith (1995) obtained higher precisions C, they were 26.1 and $28.1 \%$ compared to our results at the planting speed $8.0 \mathrm{~km} / \mathrm{h}$, while the permissible level of precision $\mathrm{C}$ is $29 \%$. Elmore (2002) also established a similar significant increase of the precision $\mathrm{C}$ with the increase of planting speed from $3.2 \mathrm{~km} / \mathrm{h}$ to $9.7 \mathrm{~km} / \mathrm{h}$

At the planting speed $11 \mathrm{~km} / \mathrm{h}$, planting density was lower from 7370 to 8222 plants per hectare than at the planting speed 7 $\mathrm{km} / \mathrm{h}$. Lower planting density at higher planting speed usually reflects the technical incapability of a planter to evenly distribute seeds on the seed plate and place them at the desired points in a planting row. This was noticed already during the planting when the computer displayed the planting density for each row. With the increase in planting speed to $9 \mathrm{~km} / \mathrm{ha}$ and $11 \mathrm{~km} / \mathrm{h}$ we saved up to 8222 seeds/ha $(10 \%)$. If a seed bag contains 25,000 seeds that means almost one third of the bag. If taking the net price of one bag at $60 €$, it means a saving of $20 €$ per hectare. Our results are not congruent with those of Nielsen (1995), who even established the increased density of plants per hectare at 9 of 22 locations when the planting speed was increased from $6.4 \mathrm{~km} / \mathrm{h}$ to $11.2 \mathrm{~km} / \mathrm{h}$. The same author indicated that the density of plants per hectare decreased when vacuum planters were used at increased planting speed, which agrees with our results, while the density of plants per hectare even increased by the planters with finger pickup mechanism. Reeves and Cox (2013) reported that optimal plant density and row spacing differ for varying field conditions, and different regions and hybrids. In addition to the periodical monitoring of the optimum rates for any location, adjusting the planting density to the specific field environment is a recommended practice.

With regard to the distances between plants in a row, the results show that the increase of planting speed from $7 \mathrm{~km} / \mathrm{h}$ to $9 \mathrm{~km} / \mathrm{h}$ and $11 \mathrm{~km} / \mathrm{h}$ with a modern air vacuum maize planter brings an increase in the plant spacing variability, and a more uneven plant distribution in a row, which is according to our hypothesis. Spacing uniformity, however, is not only ensured by the precision with which modern planters lay seeds in a row. Besides the planter itself, there are also some other factors, such as soil temperature and soil moisture, planting depth, mechanical and chemical damage of seeds and germinating plants, harmful organisms, and other factors which influence plant spacing in a row (Bullock et al., 1988; Lauer and Rankin, 2004). Our experiment did not specifically deal with these factors, as the experiment would become too extensive.

No differences were established between the three planting speeds with regard to the silage yield and the dry matter yield, despite the differences which emerged in plant spacing variability. The silage yield per plant and dry matter yield per plant increased 
despite higher plant spacing variability, and more uneven plant distribution in a row at higher planting speeds. Similar studies on the influence of planting speed on the silage yield parameters are scarce and therefore it is not possible to compare similar results. Demmel et al. (2000) compared the planting with $34 \mathrm{~cm}$ spacing between plants in the shape of a triangle with the classic planting with $75 \mathrm{~cm}$ inter-row width. With the planting in the shape of a triangle, they established 5\% higher both silage yield and dry matter yield in comparison to the classic planting at $75 \mathrm{~cm}$ inter-row width. Malasli et al. (2017) carried out no-till planting of three silage hybrids with three within-row spacings $(10,15$, and $20 \mathrm{~cm})$. They found that the time from planting to germination shortened with the increase of within-row spacing from 10 to $20 \mathrm{~cm}$. The highest silage yield of the three tested hybrids was obtained at 20 $\mathrm{cm}$ within-row spacing. Widdicombe and Thelen (2002) observed an increase in dry matter yield when the inter-row width was reduced from 76 to $38 \mathrm{~cm}$. They also established an increase in dry matter yield when the plant density increased from 64,200 to 88,900 plants per hectare.

We established that higher planting speed increased the grain yield per plant and ear parameters, such as kernel mass per ear, total ear mass, and cob mass, as well as individual kernel mass. This is due to significant decrease in plant density per hectare with the increasing planter speed. Since higher planting speed significantly results in a higher Miss Index, we suppose that the yield of the plants at miss places is higher than the yield of evenly spaced plants. This is shown by our results of the ear analysis. Tollenaar et al. (2006) cited that a moderate increase in plant spacing variability did not influence maize grain yield, because reductions in the grain yield of plants that experienced enhanced crowding stress was compensated by the increased yield of plants that experienced reduced crowding stress. Nafziger (1996) reported that the yield of plants near miss places was higher than the yield of evenly spaced plants. Results of this study did not agree with the findings of Elmore (2002) and Staggenborg et al. (2004), who established that the planting speed did not influence grain yield. In the trials they used an air vacuum planter with and without seed-firming devices at planting speeds from 6 to $12 \mathrm{~km} / \mathrm{h}$. Their trial is not directly comparable with our research, although they also obtained higher plant spacing variability at increased planting speed. By using seed firmers, they reduced plant spacing variability.

Our results are not congruent with the findings of Nielsen (1995), where the increase of planting speed from 6.4 to $11.2 \mathrm{~km} / \mathrm{h}$ increased the plant density for 1976 seeds/ha. In addition, the planting speed did not affect the plant spacing variability. Nielsen's (1995) main finding is that the influence of planting speed on plant spacing variability and yield is not significant. Results of this study cannot be directly compared with the ones from Nielsen (1995), because in that study a planter with a finger pick-up mechanism was used and the seed density amounted 65,000 seeds/ha. On the other hand, La Barge and Thomison (2001) concluded that increased planting speed brought about increased plant spacing variability and reduced the yield from 69 to $183 \mathrm{~kg} / \mathrm{ha}$ with an increase of planting speed for $1 \mathrm{~km} / \mathrm{h}$. These findings are not congruent with ours, since in our case the increased planting speed did not bring about any reduction of yield. Woli et al. (2014) reported that decreasing the planting density did not reduce the yield, where high yield returns were unlikely due to water scarcity or to a low corn suitability rating of the field. Carlson et al. (2003) found out that the optimal planting speed reduced plant spacing variability, Multiple Index, and Miss Index. Thompson (2013) reported increase of kernel mass per ear and kernel rows per ear, while reducing plant spacing variability in the year with stress growing conditions, on the contrary in the year with good growing conditions no differences appeared.

The highest negative linear correlation was observed between plant speed and plant density and between plant speed and Quality of Feed Index which is a measure of planter's accuracy. With increasing speed lower plant densities and lower accuracy is achieved. Similar negative correlation was also shown regarding standard deviation for all distances and plant density and standard deviation all and Quality of Feed Index. Plant density is also negatively correlated to standard deviation for all distances and Miss Index. Since there was significant decrease in silage yield and grain yield at higher planting speeds ( 9 and $11 \mathrm{~km} / \mathrm{h}$ ) despite lower planter accuracy it is obvious that we did not reach the planter's speed limit where the decrease of both yields would appear.

Higher planting speed has some other advantages both with regard to the fuel savings (up to $0.7 \mathrm{~L} / \mathrm{ha}$ ) and the energy savings (up to $24 \mathrm{MJ} / \mathrm{ha}$ ). It meant $15 \%$ less fuel and energy consumption at planting speed of $11 \mathrm{~km} / \mathrm{h}$ compared to planting speed of $7 \mathrm{~km} / \mathrm{h}$. According to Fröba and Funk (2005), the fuel consumption of a 4row planter is $3.631 / \mathrm{ha}$, while the planting speed is not specified. This data refers to a planter without a spreader for simultaneous fertilising. Our experiment applied an air vacuum planter with an attached spreader for simultaneous fertilising in a row with 250 $\mathrm{kg} / \mathrm{ha}$ NPK 15-15-15. The fuel consumption was thus slightly higher than it would have been had we used a planter without a spreader. Our results agree with the results of Stubbs (2013), who notes that the average fuel consumption per hectare for maize planting is $4.3 \mathrm{~L} /$ ha. Filipović et al. (2004) used a 6-row air vacuum planter, and found that the fuel consumption was $3.86 \mathrm{~L} / \mathrm{ha}$, while the energy consumption was $135.4 \mathrm{MJ} / \mathrm{kg}$. These research data are valid only for a certain planting speed, while in our experiment three planting speeds were compared.

\section{Conclusions}

Our study shows significant benefits of increased planting speed especially for saving seed (10\%) and energy (15\%), while remaining both silage and grain yields on the same level as at optimal plant speed suggested by planter producers.

Because of lower plant density at higher planting speeds significant differences appeared in silage and grain yield per individual plant and their parameters.

Planting speed had significant influence on plant spacing parameters, especially on plant density, which was lowered by the increase in planting speed.

Our research was done only on one maize hybrid. By the use of different maize hybrids different results could be obtained. Results in the study show that the upper speed limit of vacuum maize planter which would significantly affect silage and grain yield was not achieved. It seems we could also test higher planting speeds and we will be closer to the limit of the negative influence on the yield. Maybe we should also include in the experiment a lower plant speed than $7 \mathrm{~km} / \mathrm{h}$. So, further research should be done including these parameters.

\section{Highlights}

- Planting speed of vacuum planter did not influence the silage and grain yield of maize.

- At a higher planting speed up to $10 \%$ less seed was needed per hectare and fuel and energy use was reduced up to $15 \%$. 
- Silage and grain yield per individual plant increased by increasing planting speed.

- Increasing of planting speed plant density decreased.

- Plant spacing parameters were significantly affected by planting speed.

\section{References}

Bullock DG, Nielsen RL, Nyquist WE, 1988. A growth analysis comparison of maize grown in conventional and equidistant plant spacing. Crop Sci. 28:254-58.

Carlson G, Doerge T, Clay D, 2003. Estimating maize yield loss öom unevenly spaced plants. International Plant Nutrition Institute Publication, SSMG-37, 1-4.

Demmel M, Hahnenkamm O, Kormann G, Peterreins M, 2000. Equal-space seeding with forage maize. Landtechnik. 3:210-11.

Ehrbach DC, Wilkins DE, Lovely WG, 1972. Relationships between furrow opener, maize plant spacing, and yield. Agron. J. 64:702-04.

Elmore R, 2002. How does planter speed affect plant spacing? Crop Watch Journal of University of Nebraska: 1-3.

Filipović D, Košutić S, Gospodarić Z, 2004. Influence of different soil tillage systems on fuel consumption, labour requirement and yield in maize and winter wheat production. Agriculture. 10:17-23.

Fröba N, Funk M, 2005. Dieselkraftstoffbedarf bei landwirtschaftlichen Arbeiten. Kuratorium für Technik und Bauwesen in der Landwirtschaft (KTBL), Darmstadt, Germany.

Kachman SD, Smith JA, 1995. Alternative measures of accuracy in plant spacing for planters using single seed metering. Trans ASAE. 38:379-87.

Krall JM, Esechie HA, Raney RJ, Clark S, Ten Eyck G, Lundquist M, 1977. Influence of within-row variability in plant spacing on grain yield. Agron. J. 96:275-80.

La Barge G, Thomison P, 2001. Tips to reduce planter performance effects on maize yield. Ohio State University Extension, Ohioline Bulletin, USA.

Lauer JG, Rankin M, 2004. Maize respornse to within row plant spacing variation. Agron. J. 96:1464-68.

Liu W, Tollenaar M, Stewart G, Deen W, 2004. Within-row plant spacing variability does not affect maize yield. Agron. J.
96:275-80.

Malasli MZ, Khatami A, Çelik A, 2017. The effects of different plant densities and silage maize varieties on silage yield and some yield parameters in no-till seeding. Turk. J. Agric. For. 41:490-9.

Muldoon JF, Daynard TB, 1981. Effects of within-row plant uniformity on grain yield of maize. Can. J. Plant. Sci. 61:887-94.

Nafziger ED, 1996. Effects of missing and two-plant hills on maize grain yield. J. Prod. Agric. 9:238-40.

Nielsen RL, 1995. Planting speed effects on stand establishment and grain yield of maize. J. Prod. Agric. 8:391-93.

Nielsen RL, 2001. Stand establishment variability in maize. AGRY.91-01:1-10.

Reeves GW, Cox WJ, 2013. Inconsistent responses of corn to seeding rates in field-scale studies. Agron. J. 105:693-04.

Schubeck FE, Young HG, 1970. Equidistant maize planting. Crops Soils. 22:12-4.

Staggenborg SA, Taylor RK, Maddux LD, 2004. Effect of planter speed and seed firmers on maize stand establishment. Appl. Eng. Agric. 20:573-580.

Stubbs BJ, 2013. Energy usage of agricultural machinery for maize and soybean production in Brazil, India, USA and Zambia. MSc, University of Illinois, Urbana-Champaign, USA.

Thompson TA, 2013. Within-row spacing effect on individual maize plant yield. MSc, University of Illinois, UrbanaChampaign, USA.

Tollenaar M, Deen W, Echarte L, Liu W, 2006. Effect of crowding stress on dry matter accumulation and harvest index in maize. Agron. J. 98:930-7.

Vanderlip RL, Okonkwo JC, Schaffer JA, 1988. Maize response to precision of within-row plant spacing. Appl. Agric. Res. 3:116-9.

Vasilj Đ, 2000. Biometrika i eksperimentiranje u bilinogojstvu. Hrvatsko agronomsko društvo, Zagreb, Croatia.

Virk SS, Fulton JP, Porter WM, Pate GL, 2020. Row-crop planter performance to support variable-rate seeding of maize. Precis. Agric. 21:603-19.

Widdicombe WD, Thelen KD, 2002. Row width and plant density effect on maize forage hybrids. Agron. J. 94:326-30.

Woli KP, Burras CL, Abendroth LJ, Elmore RW, 2014. Optimising corn seeding rates using a field's corn suitability rating. Agron. J. 106:1523-32.

Yazgi A, 2016. Effect of seed tubes on maize planter performance. Appl. Eng. Agric. 32:783-90. 